\title{
МУЗИЧНО-ДРАМАТИЧНА ШКОЛА МИКОЛИ ЛИСЕНКА: ДО ІСТОРІї ТЕАТРАЛЬНОЇ ОСВІТИ В УКРАЇНІ
}

\begin{abstract}
У розвідиі досліджується історія драматичного відділення Музично-драматичної школи М. В. Лисенка - першої української театральної школи. Висвітлено причини й умови створення школи, їі особливості. Визначено розпорядок роботи школи. Охарактеризовано вимоги та методологічні прийоми підготовки майбутніх театральних діячів. Досліджено особливості навчального процесу (студентські вистави на сиенах міста, освітні лекиії перед початком вистав тощо). Реконструйовано педагогічний склад драматичного відділення школи Лисенка (дисиипліна і роки викладання, біографічні відомості), зібрано відомості щьодо навчальних програм. Здійснено спробу окреслити значення школи Лисенка для розвитку театральної освіти в Україні.
\end{abstract}

Ключові слова: школа Лисенка, театральна освіта, історія театру (театрознавство), Володимир Перети.

В статье исследуется история драматического отделения Музыкально-драматической школь Н. В. Лысенко - первой украинской театральной школы. Освещены причины и условия создания школь, ее особенности. Определен распорядок работы школь. Охарактеризованы требования и методологические приемы подготовки будущих театральных деятелей. Исследованы особенности учебного прочесса (студенческие спектакли на сценах города, образовательные лекции перед началом спектаклей и т.п.). Реконструирован педагогический состав драматического отделения школы Лысенко (дисииплина и годы преподавания, биографические сведения), собраны сведения об учебных программах. Предпринята попытка определить значение школь Лысенко для развития театрального образования в Украине.

Ключевые слова: икола Лысенко, театральное образование, история театра (театроведение), Владимир Перети.

The survey dwells upon the history of Drama Department of Lysenko Drama and Music School — the first Ukrainian theater school. The reasons and conditions for founding the school, as well as its features are highlighted. The school schedule is determined. The requirements and methodological techniques of teaching the upcoming theatrical personalities are defined. The features of the educational process (students 'performances on the city stages, educational lectures prior to the performances, etc.) are studied. The teaching staff of Drama Department of Lysenko School (disciplines and years of teaching, biographical data) is reconstructed, information on educational programs is compiled. An attempt to outline the importance of Lysenko School for the development of theatrical education in Ukraine is made.

Key words: Lysenko School, theatrical education, history of theater (theater studies), Vladimir Peretz.

Однією 3 ознак сформованої театральної культури (у системі уявлень XIX - початку $\mathrm{XX}$ століття) $є$ національна театральна школа, що передбачає:

- усвідомлення суспільством потреби у такій школі і здійснення кроків до ії інституалізації;

- методику практичної підготовки майбутніх театральних діячів;

- комплекс заходів, спрямованих на дослідження минулого національного і світового театру (включаючи наявність відповідних навчаль- них курсів, створення архівів, музейних колекцій тощо).

Хоча перші театральні школи на етнічній території України відомі ще з XIX століття, однак, судячи $з$ переліку практичних і теоретичних дисциплін, які викладалися у польській театральній школі (акторська гра, музика, танець, сценічні вправи, історія Польщі, всесвітня історія, міфологія й археологія, світова література, психологія, французька мова, естетика - аналіз драматичних характерів) $[1,10-25]$, їхні завдання істотно відрізнялися від 
потреб початку XX століття. Це зумовлено не лише зміною вимог до практичної підготовки учнів (техніки актора), а передусім появою нової навчальної дисципліни, народження якої стало відповіддю на потреби театру. Цією дисципліною була «історія театру», вивчення якої спрямовувалося не лише на формування ерудиції вихованців, а й на усвідомлення театрального мистецтва в усьому різноманітті його форм як самостійного виду мистецтва і засвоєння його здобутків.

Першу відому лекцію з історії театру прочитав 1845 року Роберт Прутц («Лекції з історії німецького театру») [2, 35]; в Російській імперії, за свідченням Михайла Возняка, університетський курс «Початок російського театру» 1861 року читав Микола Тихонравов $[3,141]$. Проте ця інформація викликає сумнів, адже сам М. Тихонравов не давав таку назву курсу, а лише зазначив, що «замість передмови до “Жалостливой комедии” розміщую три лекції з курсу, читані в Московському університеті у 1859/60 академічному році» $[4,7]$.

Першою достовірною датою початку викладання академічного курсу історії театру в Російській імперії є 1899 рік - з цього року Володимир Перетц, майбутній професор Київського університету св. Володимира, академік Імператорської академії наук, академік ВУАН, розпочав викладання у Петербурзькому університеті курсу «Історія театру в Росії» ${ }^{15}$ ] (в ці ж роки історія театру вже вивчається у Ляйпцигу, Бонні [6, 185], а від 1900 року дисципліну викладатиме «фундатор» театрознавства Макс Геррманн).

Першим українським навчальним закладом, де було започатковано вивчення історії театру, стала Музично-драматична школа Миколи Лисенка, прямим спадкоємцем якої є Київський національний університет театру, кіно і телебачення імені I. К. Карпенка-Карого. I хоча навчальний курс мав назву «історія драми», однак, зіставляючи його 3 науковими інтересами і методологічними підходами викладача, котрий читав цю дисципліну, Володимира Перетца, можна припустити, що викладання здійснювалося 3 акцентом на історії сценічного мистецтва.

Історія Музично-драматичної школи Миколи Лисенка, здавалося б, загальновідома. Відомо, що іiï було створено 1904 року; що на їі драматичному відділенні впродовж 1904-1918 років навчалися видатні діячі українського театру Поліна Самійленко, Софія Мануйлович, Степан Бондарчук,

\footnotetext{
1 Після В. Перетца цю дисципліну в університеті викладали І. Шляпкін (1915-1917), О. Гвоздєв (1921).
}

Прохор Коваленко, Марко Терещенко, Борис Романицький, Йона Шевченко та інші; відомо, що саме учні цієї школи у 1916-1917 роках потягнулися до театральної студії Леся Курбаса [7, 29]; що 1918 року школу було реорганізовано у Музично-драматичний інститут імені М.В.Лисенка, згодом у теа-муз-технікум, а пізніше - у Київський національний університет театру, кіно і телебачення імені І. К. Карпенка-Карого.

Однак поряд із відомими фактами в історії школи маємо велику кількість суперечливих відомостей і білих плям - особливо у зв'язку 3 першим етапом діяльності школи Лисенка (19041912) та іiі драматичного відділення. Адже за часів музично-драматичного інституту ім. Лисенка (1918-1934) архів школи було втрачено, а його пошуки досі не дали результатів ${ }^{2}$. Однак зі спогадів викладачів і вихованців школи (М. Лисенка, М. Старицької, О. Мишуги, П. Коваленка, І. Стешенко та ін.), а також авторів, котрі входили до кола М. Лисенка (М. Грушевського, С. Єфремова, Є. Чикаленка), можна відтворити окремі аспекти діяльності цього навчального закладу.

1898 року помер Станіслав Блюменфельд ${ }^{3}$, засновник приватної музичної школи, в якій викладав Микола Лисенко, i, «щоб закінчити навчальний рік, колеги обрали директором Миколу Віталійовича. Навесні після екзаменів школа мала закритися, проте її викладачі почали пропонувати М. Лисенкові відкрити свій навчальний заклад, аргументуючи, що такому видатному музичному діячеві навряд чи відмовлять» $[9,110]$. Сам композитор писав у листі до О. Самойлович: «Вчера покончили все экзамены в бывшей музыкальной школе Блюменфельда; оканчивающим по фортепьяно, пению, скрипке, теории повыдавали аттестаты, свидетельства. Поміркували, повершили діла, закрили школу та й розійшлися. Тепер уже школи С. М.Блюменфельда більше нема. Якщо

\footnotetext{
${ }^{2}$ Відомості про діяльність школи містяться у Центральному державному історичному архіві, Державному архіві Київської області, Центральному державному архіві-музеї літератури та мистецтва, Музеї театрального, музичного та кіномистецтва, Музеї видатних діячів. Інформацію про студентів інституту, починаючи з 1925 року, збирала Зінаїда Нертовська (завідувачка учбової частини інституту, що пропрацювала в інституті від заснування школи Лисенка і до післявоєнного періоду. У школі Лисенка (1910-1912) викладала на драматичному відділі обов'язковий курс фортепіанної гри). Ці дані містяться у «Книзі особового складу студентів інституту», що зберігається у відділі кадрів КНУТКіТ ім. І. К. Карпенка-Карого [8, 286].

${ }^{3}$ Станіслав Блюменфельд (1850-1898) — композитор, піаніст, педагог. Із Лисенком працював ще в інституті шляхетних дівчат, де викладав фортепіанну гру, також давав приватні уроки. 1892 року відкрив власну школу в Києві.
} 
Міністерство Вн[утренних] Дел, куда я [за підтримки М.П.Старицького] послал прошение через Драгомірова, разрешит мне, то будет нова Муз[ична] Школа Лисенка. Тільки самому мені iii не підняти. Якщо пристати до спілки зі мною грішми, то діло почати можна буде, а як ні, то розрішеніє лежатиме у кишені. Из всего видно, что большинство тех, что учились в Школе и не окончили еще ее, поступят и в новую Школу, на ее основе создаваемую. Но без средств приступить к основанию ее нет основания. Ми цього питання за браком часу не обговорювали з Вами, а треба ж, свидевшись, поговорить и принципиально, и детально» [10, 275-276].

Дозвіл Міністерства внутрішніх справ було отримано 1899 року, але за браком коштів реалізувати задум одразу не вдалося. Фінансове питання вирішилося 1903 року під час святкування 35-річчя творчої діяльності Лисенка (ця подія дістала віддзеркалення у багатьох документах зокрема, у спогадах Свгена Чикаленка [11], Сергія Єфремова [12] та ін.). «Опріч звичайних форм святкування - концертів і засідань 3 адресами та привітаннями, — згадував Сфремов, — найбільш заходу вимагала вперше, мабуть, у нас поставлена тоді думка - зібрати певну суму на "національний дарунок” ювілятові. “Звичайно, — казав дехто з скептиків, - ми не спроможемось зібрати на віллу, як поляки Сенкевичеві, - ну то хоч на сяку-таку халупу стягнемось”. Дякувати енергійним заходам та агітації організованих громадян, жертви до такого ювілейного фонду приходили частенько з різних місць, і скарбник Громади кожного разу подавав про них відомості. Тих жертв кінець-кінцем набралося на кілька тисяч карбованців...» $[13,148]$. Отримані кошти (15 тисяч карбованців [14, 244]) Лисенко вирішив використати для заснування школи. Однак незадовго до відкриття, з'ясувалося, що розпоряджатися «подарунком» за власним бажанням Лисенко не має права, тож композиторові довелося «позичати» власні гроші $[9,112]$.

1 травня 1904 року — офіційна дата заснування школи. Влітку того ж року було опубліковано Умови прийому та оголошено прийом (до всіх молодших класів та до першого класу старшого відділення), час вступних іспитів (друга половина серпня) та початок занять у Школі (1 вересня 1904 року).

Відкриття школи було широко анонсовано в українській пресі. «Бажаючи надати школі загальноукраїнського значення, він [Лисенко] розсилає для поширення у різні міста України (зокрема, в Миколаїв до Миколи Аркаса, в Одесу до Сергія
Шелухіна, у Львів до Михайла Грушевського) об'яви про відкриття нового навчального закладу, а також розміщує відповідну інформацію в багатьох (у тому числі галицьких) часописах» $[9,111]$. Так, у листі до Грушевського Лисенко писав: «Сьогодні вислав у Львів на адресу Наукового Товариства Вам два шпаргали, стосуючі до моєї Музично-Драматичної школи у Києві, що має відкритися з 1-го вересня. Умови і статут я переклав на українську мову і прошу Вас дуже, проредагувавши добре 3 боку мови, устроїти їх друком у “Віснику" і у “Ділі”. Одбитки ж з їх зробити на тонесенькому папері в тій меті, щоб можна було б ніби листом вислати - до нас, на Україну. Бо при школі враз з російською драмою і декламацією я конче хочу завести й українську декламацію для охочих студіювати в рідній мові» $[15,387]$. У листі до М. Аркаса Лисенко повторив своє прохання: «Вибачте мене, що важуся, насмілююся обважити Вас своєю прозьбою: не маю бо ні духа, крім Вас, знайомого у Миколаєві. Зробіть ласку, засиланні Вам об'явки про відкриття мною музично-драматичної школи у Києві, розклеїти у городі на людних, видних місцях, теж у банках, конторах, клубах, садах, театрах, магазинах; а то і на села послати до панів, які цікавиться можуть цією справою» [16, 384]. Невдовзі рекламну діяльність Лисенка було винагороджено: «Заявок до школи, - писав він у листі, - чимало приходить, але скільки з'явиться їх до прийому, Бог його віда» $[17,387]$.

За часів Лисенка школа, метою якої було «давати вихованцям цілком закінчену художню, музичну або драматичну освіту» $[18,7]$, розташовувалася в одноповерховому будинку з мезоніном, орендованому у лікаря-психіатра (майбутнього викладача школи) Івана Сікорського, за адресою вул. Підвальна, 15 (будинок знесено 1950 року). 1919 року школу переведено в інше приміщення на вул. Великій Володимирській, 45, де сьогодні базується Будинок учених НАН України [7, 34]. 31922 року Музично-драматичний інститут ім. Лисенка (драматичне відділення) орендував приміщення на Хрещатику, 584 (у 1875-1876 роках прибутковий будинок, у 1885-1908 роках - у будинку містився найбільший у Києві магазин-склад «Депо», майстерня і фабрика музичних інструментів Їндржишека Генріха-Ігнатія Ігнатійовича, 1914 року - Художній салон, згодом - кінотеатр). 1965 року Київському інститутові театрального мистецтва ім. І. Карпенка-Карого надано та-

\footnotetext{
${ }^{4}$ Нині цей будинок має номер 52.
} 
кож приміщення колишньої економічної школи Терещенків по вул. Ярославів Вал, 40 (навчання в корпусі було розпочато 1968 року) [7, 62].

Найдетальніший опис першої будівлі школи було записано 1979 року Роксаною Скорульською за спогадами Ірини Стешенко та накресленим нею планом. Школа мала два поверхи (хоча з вулиці здавалося, що приміщення одноповерхове) та прибудову. На фасаді висіла чорна вивіска, на якій золотом було написано: «Музыкально-драматическая школа Н. В. Лысенко». Вікна виходили на вулицю і у внутрішній двір із невеличким садком (вікна і стеля другого поверху були значно нижчі, ніж на першому поверсі). На першому поверсі було два передпокої (у першому - сходи на другий поверх, столик із кореспонденцією і швейцарська, у другому — роздягальня, дзеркало), канцелярія (зі шкіряним диваном та репродукцією «Дев'ятого валу»), клас Лисенка (рояль, декілька стільців), прохідна кімната 3 каміном («який часом горів, і коло нього Марія Михайлівна Старицька сиділа, розповідала анекдоти і взагалі історії із свого минулого життя театрального») $\mathrm{i}$, власне, зала (третину займала сцена заввишки приблизно в один метр із падугами і кулісами), кухня, вбиральня, чорний вихід, декілька музичних кабінетів. На другому поверсі були: ще один чорний вихід, ванна кімната, великий коридор, ліворуч - класи ${ }^{5}$. «При школі, - згадував Люцій Кобилянський, - утворився на початку невеликий музей, де в першу чергу зайняли місце українські народні музичні інструменти» $[19,66]^{6}$.

Школа мала два відділення: музичне і драматичне. Викладання здійснювалося за програмою Московського філармонічного музично-драматичного училища $[18,7]$, ймовірно, як продовження традиції школи Блюменфельда, який «поєднував виховання музикантів і акторів», започаткувавши своєю школою «заклад нового типу» $[20,78]$ (за іншими свідченнями навчання здійснювалося за програмами Московської та Петербурзької консерваторії $[21,583 ; 22,181])$.

Вступні іспити проводилися наприкінці серпня [23, 474]. Навчання в трьох класах драматичного відділення тривало чотири роки і було платним $[24,93]$ (від 100 до 125 карбованців на рік [25, 622];

\footnotetext{
5 Розшифрування аудіозапису спогадів І.І.Стешенко про Музично-драматичну школу М.В.Лисенка. Запис здійснено 27.04.1979 р. Оригінал запису знаходиться у фонотеці Музею Миколи Лисенка (МВДУК). Розшифрування зроблено Р. М. Скорульскою.

${ }^{6}$ Сьогодні ці музичні інструменти зберігаються у музеї Миколи Лисенка.
}

інформація про вартість навчання на музичному відділенні подавалася у щорічнику «Весь Киев: Адресная и справочная книга»), однак деяких учнів Лисенко звільняв від плати $[26,255-256]$. Про безкоштовне навчання пише й Іван Піскун, проректор, ректор (1938-1939) Музично-драматичного інституту: «За записками бухгалтерії, за спогадами самих вихованців і вихователів школи, встановлено, що такі безплатні групи талановитих дітей з бідноти були: по класу музики - у Миколи Віталійовича Лисенка, по класу вокалу в Муравйової $<\ldots>$, по драматичному класу - у М. М. Старицької» [27, 34].

До навчання зараховувалися особи віком від шістнадцяти років, яким надавалися квартири 3 повним пансіоном за усталену платню. Академічний рік тривав 31 вересня до 15 травня.

За спогадами Остапа Лисенка, який «з самого початку допомагав батькові [М. Лисенку] в адміністративних і фінансових справах школи», школа не отримувала дотацій і нерідко «батькові [М. Лисенку] доводилось влізати в борги $<\ldots>>$ ледь-ледь зводячи кінці з кінцями» $[26,255]$.

До абітурієнтів драматичного відділення висувалися такі вимоги:

«а) сценічність вроди; при тому безумовною перешкодою до вступу на курси вважаються фізичні вади в складі тіла (кульгання, горбатість), такі вади, що роблять цілком нездатним ні до якого амплуа, безпорадна зіпсованість мови (гунявість, заїкування, безпорадна шепелявість і т. и.) і занадто слабкий або негарний голос, нездатний до поправної сценічної вимови;

б) умілість поправно й поточно читати по українському і в) загальна освіта в розмірі щонайменше чотирьох клас гімназіальних. Місцева вимова не вважається за перешкоду при вступі на драматичні курси, але якщо ученик не відстане за рік від такої вимови, то не зможе перейти на вищий курс» $[28,94]$.

Дисиипліни драматичного відділення було поділено на чотири роки навчання:

«Курс перший:

а) Дикція < .. > . Помічними студіями служать: читання гекзаметра, олександрійського вірша і т. ін. < ..> теорія версифікації <..>, і спів (гамми, sons flies, сольфеджіо) для тих, хто має голос і слух.

б) Перші початки декламації: теорія артистичного читання (зупинки, назви, логічні та символічні наголоси, тон епічний, ліричний, драматичний, тон байки, розвиток плавної, текучої гармонійної мови). 
в) Історія літератури $<\ldots>$

г) Танці.

д) Фехтування і гімнастика. $<\ldots>$.

Курс другий.

a) Декламація: <..> Читання балад, ліричних поезій, байок і т. ін. і монологів із п’єс. Перші вправи діалогу. Розвиток міміки.

б) Історія літератури 2-й рік.

в) Історія культури < ..> 1-й рік.

г) Історія драми 1-й рік.

д) Танці.

е) Фехтування та гімнастика $<\ldots>>$

ж) Спів.

Курс третій.

a) Практичні вправи для сцени. Виконання драматичних творів і уривків (фрагментів) артистично-літературного репертуару, — як для розвитку сценічних здібностей кожного окремого ученика, так і для осягнення ансамблю виконання. Поруч із тим виробляється звичка до самостійної сценічної праці через самостійні репетиції, тільки за порадою професорів. Закриті вистави (спектаклі) (Генеральні репетиції) з уривків. Остаточне вияснення сценічного амплуа кожного учня.

б) Декламація <...> .

в) Історія культури - 2-й рік.

г) Історія драми - 2-й рік. Через літо перед третім курсом - самостійне студіювання авторів. $<\ldots>$

д) Танці. <...>

е) Спів <..>. Курс четвертий. Виключно практичні вправи на сцені, при тому, по змозі, становляться цілі п'єси або чималі уривки з артистично-літературного репертуару. Студіювання цілих ролей» $[28,95-96]$.

Навчання велося у кілька змін. Відділ української драми працював переважно вечорами [25, 621]. За спогадами Прохора Коваленка, на початку існування школи (1906-1910) відділ російської драми налічував 20 учнів, відділ української драми - 10-15 на кожному курсі [25, 619].

Курс української драми, яким керувала Марія Старицька, вперше було набрано у 1905-1906 навчальному році $[29,20]$ (академік Ростислав Пилипчук зазначав, що Старицька вела український курс з 1907 року [7, 27], Іван Піскун вказує 1904 рік $[27,34])$. Новину про відкриття українського курсу було повідомлено на сторінках журналу «Рідний край» $[29,20]$ і газети «Громадська думка»: «В музикально-драматичній школі М. Лисенка (Б. Подвальна, 15) отворяється 3 1-ого січня 1906 року курс української декламації і клас сценічної гри» $[30,1]$. Разом із цим, у статуті школи, затвердженому міністерством, «ні про яке навчання по класу української драми $<\ldots>$ не згадується $<\ldots>$ Лисенко навмисне не вказав відділів по класу драми, обмежившись досить двозначним визначенням “сценічна освіта"» $[27,34]$. Це підтверджують свідчення Л. М. Старицької: «В дозволі драматичного відділу не згадувалось про право заснувати при школі український відділ. М. В. Лисенко і М. М. Старицька відкрили його на свій страх» $[27,34]$. Іван Піскун не виявив і пізніших документів, які б легалізовували існування українського відділу [27, 34].

1905 року розпочалися перші відкриті та закриті учнівські концерти та вистави7 ${ }^{7}$ Щорічно проходило до 5-ти відкритих концертів і 2-3 вистави. На цих тематичних вечорах зачитувалися реферати, що їх готували викладачі теоретичних дисциплін (В. Перетц, І. Стешенко та ін.).

Силами музично-драматичної школи виставлялися концерти і спектаклі в «Просвіті», «Українському клубі», «Лук'янівському народному домі» ( з яким М. Старицька уклала договір [25, 623]), у Народній аудиторії, у польському клубі «Ognivo» і на сцені самої школи. Часто на цих вечорах головував Микола Карпович Садовський - директор Товариства українських артистів [7, 28].

В українських виданнях (газети «Рідний край», «Рада», «Громадська думка») збереглося чимало відгуків про вистави і концерти організовані силами школи Лисенка. Так, кореспондент газети «Рідний край» писав 1908 року: «Вечір 23 грудня був свого роду урочистостею для української сцени: того вечора, в Києві, в театрі Комерційного товариства, ішла по українськи п'єса Ібсена "Нора". Ставила ії - київська Просвіта, себто іiі Артистична Комісія, що складається 3 гуртка молодих артистів, переважно учнів школи Лисенка. На сей гурток покладаються надії, що він поширить і освіжить репертуар української сцени» $[31,13]$.

Характеристику діяльності школи 1908 року у листі до І.П. Андріанопольскої залишив і сам Лисенко: «...Школа моя музик[ально]-драматична, дякуючи богові, зростає з року в рік. У цьому році щось нащитують до 230 учнів. Професорам моїм добре дуже живеться: добрі гроші заробляють. Учні теж, як видно, задоволені режимом школи і наукою, яку їм тут дають. Для мене поки

\footnotetext{
7 За статутом школи «про всі влаштовувані публічні музичні вечори і сценічні вистави засновник школи своєчасно повідомляє місцеве поліційне начальство і взагалі додержує загальновстановлених і звичайних щодо цього правил 1 урядових розпоряджень» $[27,34]$.
} 
що недобре трохи, бо професори беруть до себе багато безплатних; нехай би собі брали, — то їх діло, особливо, коли трапляються талановиті люди, але коли ти не береш за їх науку грошей, то школа в кожному разі повинна брати на себе, бо вона ж содержує помешкання, яке досі коштувало 1800 р. на рік, а тепер <..> 2500 р. на рік!» [32, 412-413].

Атмосферу школи до певної міри розкриває вітальний лист Володимира Перетца до Марії Старицької: «...згадалися мені перші роки школи Лисенка, сам Мик[ола] Віт[алійович] і наша з Вами робота ... Це не особливо було давно, якихось 20 -25 років тому, але для нас це майже “давня історія”, а для сучасної молоді - навіть викопна археологія! А були ті часи — прямо героїчні — і дасть бог - майбутні українці ніколи не зрозуміють тієі обстановки, в котрій Вам доводилося прокладати шляхи для створення артиста української сцени не любителя, а того, хто володіє всіма даними сценічної техніки - по теперішньому “спеца"! Я зовсім не помилюся, якщо скажу, що з Ваших рук вийшли перші “професіонали” не аматорської гільдії, не хочу хулити останніх: серед них вершини української сцени ... Але ідея створити акторів технічно освічених для гри в сучасних, а не тільки в “танцюристих” п'єсах — народилася і виросла в стінах школи, де душею були Ви» [33].

На цьому неспростовні відомості про діяльність драматичного відділу школи закінчуються. При глибшому зануренні в історію школи виникає плутанина імен, дат і фактів. Аберація пам'яті, а саме на пам'ять свідків доводиться спиратися найбільше, призводить подеколи до доволі суперечливих тверджень. Втім, саме поміж цих спогадів містяться і реальні історичні факти, що проливають світло на діяльність школи Лисенка.

Так, у спогадах Гната Ігнатовича, - у майбутньому режисера й актора театру «Березіль», котрий в інституті Лисенка викладав систему і у 1924-1925 роках був деканом факультету, — читаємо: «Український відділ був першим та єдиним Українським Драматичним Шкільним закладом. Серед викладачів цих обох відділів [російського та українського] ми маємо - М. М. Старицьку, Ф. Гущина, Г.П. Гаєвського, академ[іка В. М.] Перетца, проф[есора I. О.] Сикорського, I. М. Стешенко, Г. Сушицького, М. Г. Бурачека, пізніше I. Мар'яненка, І. О. Стадника, О. Загарова, В.В.Сладкопевцева» $[34,40]$. Однак насправді значна частина перелічених педагогів викладала вже в інституті.

Так само викликає сумнів і характеристика Ігнатовичем школи Лисенка як україномовно- го шкільного закладу, адже, зазначав Олександр Мишуга, левову частину платоспроможних учнів становили «малороси», росіяни та поляки. Перші дві категорії природно виступали за викладання російською, поляки - українською $[35,162]$. Старицька, котра очолювала обидва драматичні відділення, викладала російською мовою і лише «українську декламацію» - українською [35, 162]. Цілком впевнено можна стверджувати, що українською мовою читав курс історії української драми Іван Стешенко [36, 9; 37, 4], тоді як майбутній академік ВУАН Володимир Перетц, чиї проукраїнські виступи сколихнули на початку століття університет св. Володимира, у школі Лисенка, ймовірно, викладав російською мовою, адже вів заняття на російських курсах. Однак небезпідставним було б ствердження, що українською мовою і Перетц, і Стешенко користувалися під час своїх лекційних виступів на концертах і вечорах, що їх полюбляли влаштовувати у школі.

Підготовка за фахом «драматичне мистецтво» включала дисципліни: дикція, постановка голосу, художнє читання, майстерність актора (ці предмети зазвичай вела М. Старицька $[25,620])$, режисура, сценічна гра.

За відомостями щорічника «Весь Киев: Адресная и справочная книга» (1904-1912), спогадами учнів школи та календарями «Просвіти» можна скласти таку картину викладання драматичного мистецтва у школі 8 :

У 1904-1927 pp. - М. Старицька (18651930), донька М. Старицького, племінниця Миколи Лисенка. У 1886-1890 роках працювала у трупі батька, у 1890 році навчалася на драматичних курсах у О. Федотова (Москва), працювала у театрах Петербурга. 1897 року - повернулася до Києва.

1904-1906 (1907) [7, 26] - С. Лепковський (1863-1939) - актор МХТ (1901-1902), актор театру «Соловцов» (1902-1905), згодом працював у антрепризі (Одеса). У 1909-1917 роках — актор Малого театру у Москві.

1907-1909 (1910) [7, 26] - Г. Матковський (1852?-1941?) - актор, режисер, антрепренер, працював актором і режисером у театрі «Соловцов» (1902-1905, 1907?), 1905 року організував антрепризу в Києві.

1908-1910 - Ф. Гущчин (1863-1912) - викладач вокалу (зокрема в Імператорському театральному училищі в Петербурзі), автор низки видань

\footnotetext{
${ }^{8}$ Вказується весь період викладання кожного з педагогів.

9 Дату народження встановлено за спогадами Л. Леонідова $[38,62]$.
} 
3 питань вокального мистецтва. Викладав у школі вокал та декламацію.

1910-1911 (1912) [7, 26] - С. Броневський артист імператорських театрів, у школі викладав мистецтво актора.

1912 - Г. Гаєвський (1872-1933) - художник, режисер театру «Соловцов» (1907-1908, 1911-1912), Українського національного театру (1917-1918), Другого театру ім. Леніна (1919), автор першого «в Україні посібника з режисури» [9, 116]; викладав режисуру та механіку сцени.

На російському відділі заняття в різні роки вели: М. Старицька, С. Бронєвський, Г. Гаєвський та Є. Лепковський.

Інші дисципліни викладали:

К. Чекеруль-Куш (1872-1940) - адвокат, присяжний повірений, перекладач, політичний діяч, навчався у Московському університеті, але освіту не закінчив через революційну діяльність (1908 року викладав ораторське мистецтво);

С. Ленчевський - хореограф і танцівник польського походження, працював у Варшавському театрі, у 1892(1897?)_-1909 роках — балетмейстером Київської опери, здійснив перші хореографічні композиції української тематики («Жнива в Малоросії», «Приморське свято», «Малоросійське весілля»), у 1905-1906 роках викладав пластику і танці.

I. Сікорський (1842-1919) - психолог, приват-доцент психіатрії і нервових хвороб, екстраординарний професор університету св. Володимира, засновник Лікарсько-педагогічного інституту для розумово відсталих та нервових дітей, 3 1907 року - директор Київського педагогічного фребелівського інституту, у школі Лисенка впродовж 1908-1912 років викладав фізіогноміку.

О. Анохін (1882-1920) - лікар, тренер, педагог і теоретик спорту, перший у Києві власник диплому тренера з важкої атлетики (1908), з 1913 року - голова олімпійського комітету, редактор журналу «Краса і сила», 1910 року у школі Лисенка викладав гімнастику.

М.Ланге - польський балетмейстер, прима-балерина Київської опери (у 1907-1911 роках викладала танець; Прохор Коваленко стверджував, що Ланге вела і фехтування [25, 622]).

Кузьмін ${ }^{10}$ - історію костюма (також викладав історію побуту, фехтування [25, 622]).

До викладання теоретичних дисциплін, зокрема історії театру і драми, було запрошено видатних тогочасних вчених:

\footnotetext{
10 Можливо, йдеться про київського мистецтвознавця Свгена Михайловича Кузьміна (1864-1942) [39, 317].
}

1904-1906 [40, 67] - В. Перетц, який став першим викладачем історико-теоретичних дисциплін, заклавши тим самим основу для академічного викладання у школі Лисенка. У 1912-1914 роках читав курс з історії європейського театру та драматичної літератури в театральному училищі Товариства Мистецтв та Літератури [40, 68].

1907-1908 - граф Ф. Г. де Ла Барт (18701915) - літературознавець, історик західної літератури. Випускник Петербурзького університету (учень О.Веселовського), приват-доцент Київського та Московського університету, у своїх дослідженнях спирався на порівняльно-історичний, формально-емпіричний, психологічний методи, пропагуючи поєднання кількох методів.

1909-1912 - Г.Александровський (18731936, 1941?) — український літературознавець, педагог, громадський діяч, випускник історико-філологічного факультету університету св. Володимира (1895). Разом із братом І. Александровським один із засновників газети «Киевские отклики», член товариства «Просвіта» (1906).

1906-1912 - I. Стешенко (1873-1918) - літературознавець, громадський та політичний діяч, педагог, випускник історико-філологічного факультету Київського університету (1896). 31896 року, через громадську діяльність, Стешенкові заборонили викладати та проживати в університетських містах. Заборону було знято 1906 року. На російському відділенні Іван Стешенко викладав логіку, естетику та психологію, а на українському - історію української драми [41, IV]. Цю дисципліну Стешенко розпочав викладати 1906 року [42, 402], з моменту іiі введення до програми школи $[43,495]$.

Історія викладання «історії театру» («історії драми») у школі Лисенка — чи не найбільш заплутана. Встановити, хто, коли i, зрештою, яку саме дисципліну викладав, доволі важко. Передусім це пов'язано із назвою дисципліни. У довіднику «Весь Киев» (1904-1912), імовірно, подається узагальнена назва - «історія драми», адже у програмі школи (1904) теоретичні предмети чітко розділено на історію літератури, історію культури й історію драми.

Дослідник історії Музично-драматичної школи Лисенка М.Кузьмін вважає, що Володимир Перетц викладав історію російської драми, Фердинант де Ла Барт - історію західноєвропейської літератури, а Орест Левицький (1848-1922) - icторик, етнограф, письменник, випускник історико-філологічного факультету Київського університету (1874), член «Старої громади», «Київсько- 
го літературно-артистичного товариства», редактор, автор газети «Киевская старина» - історію української літератури $[44,40]$.

Збереглися програми курсу 3 iсторії українського театру, до якої входили такі розділи: «Вертепна драма. Містерія XVII віку. Ф.Прокопович; шкільна драма XVIII віку; інтермедії: Довгалевський, Лащевський, Георгій Кониський, Щербацький, діалоги Некрашевича. Нова драма XIX віку. Етнографічно-побутова драма Котляревського, Гоголь (батько), Квітка, Кухаренко, Тополя. Початок історичної драми. Стороженко, Шевченко, Куліш, Костомаров. Початок постійного українського театру. Драматичні переробки. Соціально-побутова та історична драма. Старицький, Карпенко-Карий, Кропивницький, П. Мирний, Яновський, Грінченко, Тогобочний та ін. Галицько-український театр» $[44,40]$.

Назв курсу, який читав Перетц, безліч: «історія драми» $[40,67]$, «історія західноєвропейського театру», «історія західноєвропейського та російського театру і драми» $[9,116]$, «історія драматичного мистецтва і літератури» [44, 37], «історія російської та української літератури» $[24,90 ; 26$, 245], «історія літератури і фольклор» [7, 27].

Так само суперечлива інформація і стосовно років викладання історії театру. Прохор Коваленко, який закінчив школу 1910 року, згадував: «Обов'язкові допоміжні предмети викладали кращі київські педагоги: історію російської драми Александровський, європейської - Перетц, української - Стешенко» $[25,622]$. Однак цей спогад викликає сумнів. Головне питання - роки викладання Перетца: Ростислав Пилипчук зазначає, що Перетц викладав у школі у 1904-1913 роках $[7,27]$ (до свого від'їзду в Петербург), однак ця інформація не підтверджується іншими джерелами, зокрема у автобіографії Перетц визначає 1904-1906 як роки викладання у школі $[40,68]$.

Незважаючи на заплутаність історичних фактів, беззаперечним залишається одне - саме ці перші курси з історії театру, прочитані видатними дослідниками початку XX століття, заклали основу для становлення театрознавства як самостійної навчальної дисципліни.

1912 року, після смерті Лисенка, школу було перейменовано на його честь. 1918 року на базі школи було створено Музично-драматичний інститут (Муздрамін) ім. М.В. Лисенка. 1934 року музичний відділ інституту увійшов до складу консерваторії, а на основі драматичного було створено Київський державний театральний інститут.
Саме тут, на базі фундаментальних досліджень і курсів, читаних видатними істориками театру Володимиром Перетцом (1904 1908), Олександром Киселем (у музично-драматичному інституті, 1918-1920), Петром Руліним (там само, 1920-1934) та багатьма іншими, було закладено грунт академічного театрознавства як самостійної дисципліни. I, нарешті, 1944 року в інституті було створено спеціалізацію «театрознавство».

\section{Джерела та література}

1. Маршалек А.Польська театральна школа у Львові 1869-1872 pр. // Вісник Львівського університету. Серія: мистецтвознавство. - Вип. 2. - Львів, [б. в.], 2002. C. $10-25$.

2. Гвоздев А. Итоги и задачи научной истории театра // Задачи и методы изучения искусств : Сб. / Отв. ред. Некрылова А. - Пг. : Academia, 1924. - C. 81-122.

3. Возняк М. [рец.] Стара українська драма і новійші досліди над нею. Рецензія на книгу - В.И. Рязанов. Из истории русской драмы. - М., 1910 // Записки Наукового товариства імені Шевченка / Під ред. Грушевського М. Львів, Друк. Наук. Товариства ім. Шевченка, 1912. T. CXII. - C. 139-191.

4. Тихонравов Н. Жалостная комедия об Адаме и Еве // Летописи русской литературы и древоности. - М. : Типография Грачева и Коми, 1861. - Т. III. - С. 7-47.

5. Перетц Владимир Николаевич. Биографика СПБГУ [ел. pecypc]. URL:http://bioslovhist.history.spbu.ru/component/ fabrik/details/1/223.html?listid_=1

6. Копелев Л. [Лев К.]. Театроведение. Германия // Театральная Энциклопедия. - М. : Советская энциклопедия, 1967. - Дополнения. Указатель. - С. 183-186.

7. Київський національний університет театру, кіно і телебачення ім. І. К. Карпенка-Карого. 100 років : Ювілейний збірник / Упорядн. і ред. Безгін I. ; істор. нарис і ред. Пилипчук Р. - К. : ВВП «Компас», 2004. - 312 с.

8. Черкашин Р., Фоміна Ю. Ми - березільці. Театральні спогади-роздуми / Р. Черкашин, Ю. Фоміна. - Харків : Акта, 2008. - $335 \mathrm{c}$.

9. Антонець Н. Внесок музично-драматичної школи М. Лисенка в розвиток мистецької освіти в Україні (19041918) // Нариси з історії розвитку новаторських навчально-виховних закладів в Україні (XX століття) / За ред. Сухомлинської О., Курила В. - Луганськ, ЛНУ імені Тараса Шевченка, 2010. - С. 106-121.

10. Лисенко М. Лист до Самойлович О. Л. від 1 травня 1898 р. // Лисенко М. Листи ; упоряд. Скорульська Р. К. : Музична Україна, 2004. - С. 275-276.

11. Чикаленко Є.Зібрання творів і листів у семи томах. К. : Рада, 2003. - Т. 1 : Спогади (1861-1907). — 432 с.

12. Єфремов С. Торжество украинской песни // Киевская старина. - К. : Типография Императорского университета св. Владимира, 1904. - Кн. 1. - С. 141-154.

13. Єфремов С. 3 Лисенком до Галичини Зі споминів і нотаток. Публікація Ростислава Пилипчука // Дзвін. 1991. — № 7 (липень). - С. 147-151.

14. Кошиць О. Спогади : у 2 т. / О. Кошиць. - Вінніпег-Манітоба // Культура й освіта, 1948. — Т. 2. — 272 с.

15. Лисенко М. Лист до Грушевського М. С. 1 липня 1904 року // Микола Лисенко. Листи / Упоряд. Скорульська Р. - К. : Музична Україна, 2004. - С. 387.

16. Лисенко М. Лист до Аркаса М. М. 27. V. 1904 // Микола Лисенко. Листи / Упоряд. Скорульська Р. - К. : Музична Україна, 2004. - С. 384. 
17. Лисенко М. Лист до Масляникової К. М. 11. VII. 1904 // Микола Лисенко. Листи / Упоряд. Скорульська Р. - К. : Музична Україна, 2004. - С. 387.

18. Условия приёма в Музыкально-драматическую школу Н. В. Лысенка // Киевская старина. - К. : Типография Императорского университета св. Владимира, 1904. Июль-август. - Приложение. - С. 7-9.

19. Кобилянський Л. Микола Лисенко (біогр. нарис) / // Популярна бібліотека. - Львів : Накладня Михайла Таранька, 1930. — Ч. 2. - 93 с.

20. Шамаєва К. Фелікс Блюменфельд у Києві // Часопис Національної музичної академії України імені П. І. Чайковського / Гол. ред. Рожок В. - К., 2013. - № 4. - С. 78-85.

21. Біографічна довідка / Шевчук В.Страсті за Миколаєм. Микола Лисенко. - К. : Пульсари, 2007. С. 579-600.

22. Архімович Л., Гордійчук М.М. Лисенко. Життя і творчість / Л. Архімович, М. Гордійчук. — К. : Музична Україна, 1992. - Вид. 3-тє, доп. і перероб. - $256 \mathrm{c.}$

23. Лисенко М. Лист до Стебницького П. Я. 26/13. VII. 1912 // Микола Лисенко. Листи / Упоряд. Скорульська Р. - К. : Музична Україна, 2004. - С. 473-474.

24. Лисенко О. Про Миколу Лисенка: Спогади сина / О. Лисенко. - К. : Радянський письменник, 1957. — 155 с.

25. Коваленко П.Перша українська музично-драматична школа та їі організатор М. В. Лисенко // М. В. Лисенко у спогадах сучасників / Упор. Лисенко О. ; ред. та комент. Пилипчук Р. — К. : Музична Україна, 1968. - С. 619-623.

26. Лисенко О. М. В. Лисенко. Спогади сина / О. Лисенко. К. : Мистецтво, 1966. - 366 с.

27. Піскун I. Театральна освіта на Україні // Театр. - 1938. № 4, липень-серпень. - С. 34-37.

28. Музично-драматична школа М. В. Лисенка в Києві // Літературно-науковий вісник. - Львів : Друкарня Наукового Товариства ім. Шевченка, 1904. — Річник VIII. T. XXVII. - C. 92-96.

29. Рідний край. - Полтава, 1906. - № 1.

30. Громадська думка. - К., 1905. — № 1. - 31 грудня.

31. Українське слово і мистецтво : П'єса Ібсена на українській сцені // Рідний край. — К., 1908. — № 42.

32. Лисенко М.Лист до Андріанопольської І. П. від 24.04.1908 // М.В.Лисенко. Листи / Упоряд. Лисенко О. - К. : Мистецтво, 1964. - С. 412-413.

33. Перетц В. Лист до Старицької М. М. від 29.03.1927 // Музей Михайла Старицького. - Кн. 6236. - Л-81. - 1 арк.

34. Ігнатович Г. Драматичний факультет // Державний музично-драматичний інститут ім. Лисенка. 1903-1913-1928 / Г. Ігнатович. - К. : Держтрест «Київ-Друк». - С. 39-48.

35. Олександр Мишуга: спогади, матеріали, листи / Упоряд. Головащенко М. - К. : Музична Україна, 1971. — 778 с.

36. Про українські кафедри і про курси українознавства // Рідний край. - Полтава, 1906. — № 48.

37. Про українські кафедри і про курси українознавства // Рідний край. - Полтава, 1907. — № 2.

38. Леонидов Л. Воспоминания, статьи, беседы, переписка, записные книжки / Л. Леонидов. - М. : Искусство, 1960. - $756 \mathrm{c}$.

39. Веселовська Г. Іменний покажчик / Веселовська Г. Театральні перехрестя Києва, 1900-1910-х рр. (Київський театральний модернізм). — К. : ДЦТМ імені Леся Курбаca, 2006. - С. 301-335.

40. Перетц В. Перетц, Владимир Николаевич // Материалы для биографического словаря действительных членов Императорской Академии Наук : в 2 ч. - Пг. : Тип. Императорской Академии наук, 1917. — Ч. 2., М-Я. С. 65-72.

41. Музично-драматична школа М.В. Лисенка. Оповістки // Календар Просвіти. — 1907. — Рік Перший. - К., 1906. - C. IV.
42. Лисенко М. Лист до Комарова М. Ф. від 02.08.1906 // Микола Лисенко. Листи / Упоряд. Скорульська Р. - К. : Музична Україна, 2004. - С. 402.

43. Лисенко О. Примітки // М. В. Лисенко. Листи. - К. : Мистецтво, 1964. - С. 435-502.

44. Кузьмін М. Музично-драматична школа М. В. Лисенка // Українське музикознавство : Зб. — К. : Музична Україна, 1984. - Вип. 19. - С. 37-50.

\section{References}

1. Marshalek, A.Polska teatralna shkola u Lvovi 18691872 rr. // Visnyk Lvivskoho universytetu. Seriia: mystetstvoznavstvo. - Vyp. 2. - Lviv, [b. v.], 2002. - S. $10-25$.

2. Gvozdev, A. Itogi i zadachi nauchnoy istorii teatra // Zadachi i metodyi izucheniya iskusstv : Sb. / Otv. red. Nekryilova A. Pg. : Academia, 1924. - S. 81-122.

3. Vozniak, M. [rets.] Stara ukrainska drama i noviishi doslidy nad neiu. Retsenziia na knyhu - V. Y. Riazanov. Yz ystoryy russkoi dramy. - M., 1910 // Zapysky Naukovoho tovarystva imeni Shevchenka / Pid red. Hrushevskoho M. — Lviv, Druk. Nauk. Tovarystva im. Shevchenka, 1912. - T. SKhII. - S. 139-191.

4. Tihonravov, N. Zhalostnaya komediya ob Adame i Eve // Letopisi russkoy literaturyi i drevonosti. - M. : Tipografiya Gracheva i Komi, 1861. - T. III. - S. 7-47.

5. Peretts, Vladimir Nikolaevich. Biografika SPBGU [el. resurs]. URL. Retrieved from :http://bioslovhist.history.spbu. $\mathrm{ru} /$ component/fabrik/details/1/223.html?listid_=1

6. Kopelev, L. [Lev K.]. Teatrovedenie. Germaniya // Teatralnaya Entsiklopediya. - M. : Sovetskaya entsiklopediya, 1967. Dopolneniya. Ukazatel. - S. 183-186.

7. Kyivskyi natsionalnyi universytet teatru, kino i telebachennia im. I. K. Karpenka-Karoho. 100 rokiv : Yuvileinyi zbirnyk / Uporiadn. i red. Bezghin I. ; istor. narys i red. Pylypchuk R. - K. : VVP «Kompas», 2004. - 312 s.

8. Cherkashyn, R., Fomina, Yu. My — bereziltsi. Teatralni spohady-rozdumy / R. Cherkashyn, Yu. Fomina. - Kharkiv : Akta, 2008. - $335 \mathrm{~s}$.

9. Antonets, N. Vnesok muzychno-dramatychnoi shkoly M. Lysenka v rozvytok mystetskoi osvity v Ukraini (19041918) // Narysy z istorii rozvytku novatorskykh navchalnovykhovnykh zakladiv v Ukraini (KhKh stolittia) / Za red. Sukhomlynskoi O., Kuryla V. - Luhansk, LNU imeni Tarasa Shevchenka, 2010. - S. 106-121.

10. Lysenko, M. Lyst do Samoilovych O. L. vid 1 travnia 1898 r. // Lysenko M. Lysty ; uporiad. Skorulska R. - K. : Muzychna Ukraina, 2004. - S. 275-276.

11. Chykalenko, Ye. Zibrannia tvoriv i lystiv u semy tomakh. K. : Rada, 2003. — T. 1 : Spohady (1861-1907). — 432 s.

12. Efremov, S. Torzhestvo ukrainskoy pesni // Kievskaya starina. - K. : Tipografiya Imperatorskogo universiteta sv. Vladimira, 1904. - Kn. 1. - S. 141-154.

13. Iefremov, S. Z Lysenkom do Halychyny Zi spomyniv i notatok. Publikatsiia Rostyslava Pylypchuka // Dzvin. 1991. — № 7 (lypen). — S. 147-151.

14. Koshyts, O. Spohady : u 2 t. / O. Koshyts. - VinnipehManitoba // Kultura y osvita, 1948. - T. 2. - 272 s [in Canada].

15. Lysenko, M. Lyst do Hrushevskoho M. S. 1 lypnia 1904 roku // Mykola Lysenko. Lysty / Uporiad. Skorulska R. K. : Muzychna Ukraina, 2004. - S. 387.

16. Lysenko, M. Lyst do Arkasa M. M. 27. V. 1904 // Mykola Lysenko. Lysty / Uporiad. Skorulska R. - K. : Muzychna Ukraina, 2004. - S. 384.

17. Lysenko, M. Lyst do Maslianykovoi K. M. 11. VII. 1904 // Mykola Lysenko. Lysty / Uporiad. Skorulska R. - K. : Muzychna Ukraina, 2004. — S. 387. 
18. Usloviya priYoma v Muzyikalno-dramaticheskuyu shkolu N. V. Lyisenka // Kievskaya starina. - K. : Tipografiya Imperatorskogo universiteta sv. Vladimira, 1904. - Iyulavgust. - Prilozhenie. - S. 7-9.

19. Kobylianskyi, L. Mykola Lysenko (biohr. narys)/// Populiarna biblioteka. - Lviv : Nakladnia Mykhaila Taranka, 1930. Ch. 2. $-93 \mathrm{~s}$.

20. Shamaieva, K. Feliks Bliumenfeld u Kyievi // Chasopys Natsionalnoi muzychnoi akademii Ukrainy imeni P. I. Chaikovskoho / Hol. red. Rozhok V. - K., 2013. № 4. - S. 78-85.

21. Biohrafichna dovidka / Shevchuk V. Strasti za Mykolaiem. Mykola Lysenko. - K. : Pulsary, 2007. - S. 579-600.

22. Arkhimovych, L., Hordiichuk, M. M. Lysenko. Zhyttia i tvorchist / L. Arkhimovych, M. Hordiichuk. - K. : Muzychna Ukraina, 1992. - Vyd. 3-tie, dop. i pererob. - $256 \mathrm{~s}$.

23. Lysenko, M. Lyst do Stebnytskoho P. Ya. 26/13. VII. 1912 // Mykola Lysenko. Lysty / Uporiad. Skorulska R. - K. : Muzychna Ukraina, 2004. - S. 473-474.

24. Lysenko, O. Pro Mykolu Lysenka: Spohady syna / O. Lysenko. - K. : Radianskyi pysmennyk, 1957. — $155 \mathrm{~s}$.

25. Kovalenko, P.Persha ukrainska muzychno-dramatychna shkola ta yii orhanizator M. V. Lysenko // M. V. Lysenko u spohadakh suchasnykiv / Upor. Lysenko O. ; red. ta koment. Pylypchuk R. - K. : Muzychna Ukraina, 1968. - S. 619623.

26. Lysenko, O. M. V. Lysenko. Spohady syna / O. Lysenko. K. : Mystetstvo, 1966. - $366 \mathrm{c}$.

27. Piskun, I. Teatralna osvita na Ukraini // Teatr. — 1938. № 4, lypen-serpen. - S. 34-37.

28. Muzychno-dramatychna shkola M. V. Lysenka v Kyievi // Literaturno-naukovyi visnyk. - Lviv : Drukarnia Naukovoho Tovarystva im. Shevchenka, 1904. - Richnyk VIII. T. XXVII. - S. 92-96.

29. Ridnyi krai. — Poltava, 1906. - № 1.

30. Hromadska dumka. — K., 1905. — № 1. - 31 hrudnia.

31. Ukrainske slovo i mystetstvo : Piesa Ibsena na ukrainskii stseni // Ridnyi krai. - K., 1908. — № 42.
32. Lysenko, M. Lyst do Andrianopolskoi I. P. vid 24.04.1908 // M. V. Lysenko. Lysty / Uporiad. Lysenko O. - K. : Mystetstvo, 1964. - S. 412-413.

33. Peretts, V. Lyst do Starytskoi M. M. vid 29.03.1927 // Muzei Mykhaila Starytskoho. - Kn. 6236. — L-81. - 1 ark.

34. Ihnatovych, H. Dramatychnyi fakultet // Derzhavnyi muzychno-dramatychnyi instytut im. Lysenka. 1903-19131928 / H. Ihnatovych. - K. : Derzhtrest «Kyiv-Druk». - S. 39-48.

35. Oleksandr Myshuha: spohady, materialy, lysty / Uporiad. Holovashchenko M. - K. : Muzychna Ukraina, 1971. — 778 s.

36. Pro ukrainski kafedry i pro kursy ukrainoznavstva // Ridnyi krai. - Poltava, 1906. - № 48.

37. Pro ukrainski kafedry i pro kursy ukrainoznavstva // Ridnyi krai. - Poltava, 1907. - № 2.

38. Leonidov, L. Vospominaniya, stati, besedyi, perepiska, zapisnyie knizhki / L. Leonidov. — M. : Iskusstvo, 1960. — 756 s. [in Russian]. Tekst dlya perekladu

39. Veselovska, H. Imennyi pokazhchyk / Veselovska H. Teatralni perekhrestia Kyieva, 1900-1910-kh rr. (Kyivskyi teatralnyi modernizm). - K. : DTsTM imeni Lesia Kurbasa, 2006. S. 301-335.

40. Peretts, V.Peretts, Vladimir Nikolaevich // Materialyi dlya biograficheskogo slovarya deystvitelnyih chlenov Imperatorskoy Akademii Nauk : v 2 ch. - Pg. : Tip. Imperatorskoy Akademii nauk, 1917. - Ch. 2., M-Ya. - S. 65-72 [in Russian].

41. Muzychno-dramatychna shkola M. V. Lysenka. Opovistky // Kalendar Prosvity. — 1907. — Rik Pershyi. — K., 1906. — S. IV.

42. Lysenko, M. Lyst do Komarova M. F. vid 02.08.1906 // Mykola Lysenko. Lysty / Uporiad. Skorulska R. - K. : Muzychna Ukraina, 2004. - S. 402.

43. Lysenko, O. Prymitky // M. V. Lysenko. Lysty. - K. : Mystetstvo, 1964. - S. 435-502.

44. Kuzmin, M. Muzychno-dramatychna shkola M. V. Lysenka // Ukrainske muzykoznavstvo : Zb. - K. : Muzychna Ukraina, 1984. - Vyp. 19. - S. 37-50. 